\title{
Huge Sellar Plasmacytoma as Differential Diagnosis of Invasive Pituitary Adenoma: A Case Report
}

\section{Plasmocitoma selar enorme como diagnóstico diferencial de adenoma hipofisário invasivo: um relato de caso}

\author{
J. A. Filgueira-Junior ${ }^{1}$ \\ M. H. Dornelas ${ }^{1}$ \\ R. Barboza-Filho ${ }^{1}$ \\ D. B. Basílio \\ R. J. B. Valadares ${ }^{3}$ \\ B. A. Barbosa ${ }^{1}$
}

${ }^{1}$ Department of Neurosurgery, Hospital de Base do Distrito Federal, Brasília, DF, Brazil

2 Department of Pathology, Hospital de Base do Distrito Federal,

Address for correspondence J. A. Filgueira-Junior, Departamento de Neurocirurgia, Hospital de Base do Distrito Federal, Brasília, DF, Brazil Brasília, DF, Brazil

${ }^{3}$ Department of Otorhinolaryngology, Hospital de Base do Distrito Federal, Brasília, DF, Brazil

Arq Bras Neurocir 2021;40(2):e159-e161.

\section{Abstract \\ Keywords \\ - sellar plasmacytoma \\ - multiple myeloma \\ - parasellar mass \\ - differential diagnosis}

\section{Resumo}

\section{Palavras-chave}

- plasmacitoma selar

- mieloma múltiplo

- massa parasselar

- diagnóstico diferencial
Sellar plasmacytomas are rare tumors arising from plasma cells. They are often misdiagnosed as adenomas. We report the case of a 63-year-old woman with headache, cranial nerve III palsy and decreased visual acuity. Imaging revealed an extensive lesion centered on the clivus, extending to the cavernous sinus bilaterally and into the sphenoid sinus. The hormonal tests were compatible with panhypopituitarism and mild hyperprolactinemia. The first hypothesis was invasive pituitary adenoma. Partial resection was achieved, and the immunohistochemical evaluation was compatible with plasmacytoma. After a few weeks, she developed lumbar and hip pain, and the imaging confirming osteolytic lesions. The final diagnosis was multiple myeloma.

Plasmacitomas selares são tumores raros originados de células plasmáticas. Freqüentemente são diagnosticados erroneamente como adenomas. Relatamos o caso de uma mulher de 63 anos com cefaleia paralisia dos nervos cranianos III e diminuição da acuidade visual. A imagem revelou uma lesão extensa centrada no clivus estendendose para o seio cavernoso bilateralmente e para o seio esfenoidal. Os testes hormonais foram compatíveis com pan-hipopituitarismo e hiperprolactinemia leve. A primeira hipótese era adenoma hipofisário invasivo. Foi realizada ressecção parcial e a avaliação imunoistoquímica compatível com plasmocitoma. Após algumas semanas ela desenvolveu dor lombar e no quadril e a imagem confirmando lesões osteolíticas. O diagnóstico final foi mieloma múltiplo. received

July 6,2020

accepted

March 9, 2021

published online

August 3, 2021
DOI https://doi.org/

10.1055/s-0041-1731062. ISSN 0103-5355. (c) 2021. Sociedade Brasileira de Neurocirurgia. All rights reserved.

This is an open access article published by Thieme under the terms of the Creative Commons Attribution-NonDerivative-NonCommercial-License, permitting copying and reproduction so long as the original work is given appropriate credit. Contents may not be used for commercial purposes, or adapted, remixed, transformed or built upon. (https://creativecommons.org/ licenses/by-nc-nd/4.0/)

Thieme Revinter Publicações Ltda., Rua do Matoso 170, Rio de Janeiro, RJ, CEP 20270-135, Brazil 


\section{Introduction}

Plasmacytomas of the sellar region were first reported in 1970 by postmortem pathologic diagnosis, an observation that predates a case from 1977 that was previously attributed as the first. ${ }^{1}$ They are rare tumors localized on the sellar region arising from plasma cells. ${ }^{2}$ It is believed that the entity originates from the surrounding mucosa of the sellar region and clivus, which can be locally aggressive. ${ }^{3}$ Plasmacytomas are often misdiagnosed as adenomas due to the rarity of this disease and the limited clinical experience of entity in this location. The pathological study shows distinct plasmacytoid features, including prominent nucleoli. Another differential diagnosis is chordoma. We report the case of a patient diagnosed with sellar plasmacytoma and associated hypopituitarism followed by the discovery of multiple myeloma.

\section{Case Report}

A 63-year-old female with well-controlled hypertension presented with a 5-month frontal headache and 3-month impaired visual acuity, worse in the left eye. The admission neurological exam was notable for a slowly reactive left pupil and left CN III palsy, with ptosis. Computed tomography (CT) imaging demonstrated homogeneous expansive lesion with epicenter in the clivus, invading the sphenoid sinuses and with erosion of dorsum sellae and anterior clinoids bilaterally (-Fig. 1D). Selar magnetic resonance imaging (MRI) revealed a $4.6 \times 4.6 \times 3 \mathrm{~cm}$ homogeneously contrast enhancing lesion. There was extension into the bilateral cavernous sinuses, surrounding the cavernous carotid artery bilaterally, and into the sphenoidal sinus, sellar region, optic canal, and
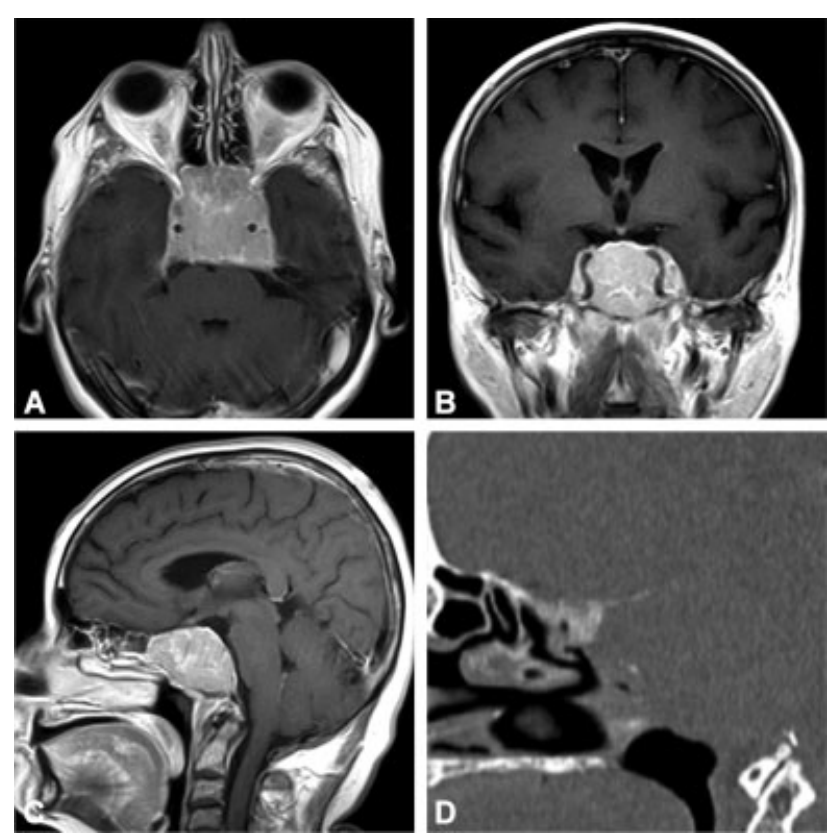

Fig. 1 Contrast-enhanced magnetic resonance imaging scan showing a homogeneously enhanced lesion centered in the clivus, with extension into the sphenoid sinus and bilateral cavernous sinus (A, B e C). Computed tomography scan showing the destroyed clivus and the invaded sphenoid sinus (D).



Fig. 2 Pathological study revealing proliferation of plasmacytoid cells with abundant basophilic cytoplasm, perinuclear hof, round eccentric nuclei, "clock face" chromatin and indiscernible nucleoli (A and B). The immunohistochemical study revealed tumor cells positive to CD138 (C) and kappa chain (D).

superior orbital fissures (-Figs. 1A, 1B and 1C). Endocrine evaluation demonstrated mild hyperprolactinemia [43.78 $\mathrm{ng} / \mathrm{dl}$ (5.18-26.53 ng/dl)], hypocortisolemia (3.4 ug/dl [3.7-19.4 ug/dl]) and low T4 level $(0.57 \mathrm{ng} / \mathrm{dl}$ [0.7-1.8 $\mathrm{ng} / \mathrm{dl}]$ ) characterizing panhypopituitarism. We found no evidence of renal insufficiency, anemia, bone pain, or hypercalcemia. The patient was diagnosed presumptively with a nonfunctioning pituitary macroadenoma and underwent endoscopic endonasal transsphenoidal approach for resection of the lesion. However, because of clinically important hemorrhage, the procedure was aborted after resection of $\sim$ $30 \%$ of the mass. After the surgery, there was mild improvement in visual acuity. Three weeks after hospital discharge, the patient presented atraumatic lumbar and hip pain. She underwent a hip MRI that found multiple heterogeneous osteolytic lesions affecting the pelvic bones and proximal femurs, as well as hip joint effusion. Immunoglobulin electrophoresis revealed monoclonal IgA/Kappa peak. The final surgical pathology evaluation of sellar mass confirmed immunopositive expression for Kappa light chain (CD138 and Kappa positives) consistent with plasmacytoma (-Fig. 2C and 2D). It was negative for Lambda chain, chromogranin, and CAM 5.2. The bone marrow biopsy showed no obvious finding of plasma cell proliferation.

\section{Discussion}

The most prevalent sellar/parasellar tumor is pituitary adenoma, which presents more often with visual field deficits than cranial neuropathies. Another condition that should be considered for differentiation is chordoma. ${ }^{3}$ Lee et al., ${ }^{2}$ after reviewing 70 cases of sellar plasmacytoma (including 65 
cases reported from literature), found the following results: slight predominance in male subjects ( $57 \%$ males vs $43 \%$ females), median age of 59 years old, and hyperprolactinemia in $38 \%$ of the patients (median level $36.7 \mathrm{ng} / \mathrm{mL}$ ). The majority of the patients presented with mass effect symptoms, including headaches in $70 \%$, cranial nerve palsies in $65 \%$, and visual disturbances in $\sim 80 \%$. DiDomenico and Ampie et al., ${ }^{1}$ in a review of 31 cases (including a new described), found a predominance in male subjects (55\% vs $45 \%$ ), and median age of 61 years old. The cranial nerve more affected is the abducens. ${ }^{1}$ The case reported was a woman, slightly older, with clinical presentation similar to that described in the literature. The endocrinological pattern differed, as it describes hypopituitarism in only $\sim 15 \%$ of cases. Our case presented with panhypopituitarism and hyperprolactinemia, the last due to stalk effect. It is unusual to find well preserved anterior pituitary function in cases of pituitary adenoma with extensive sellar fossa and clivus destruction. ${ }^{3}$ The size of the tumor also differed from the studies reviewed. The mean was $3.4 \mathrm{~cm}$ (ranging from $0.9--$ $3.9 \mathrm{~cm}, \mathrm{n}: 12),{ }^{1}$ while the tumor described was $4.6 \mathrm{~cm}$ in its greatest extent. To all the references, sellar plasmacytoma have a greater propensity for cavernous sinus invasion and erosion of the parasellar bone, including the cranial nerve foramina. ${ }^{1}$ Light microscopy examination might not always be helpful in the differential diagnosis of a parasellar mass, because the features of poorly differentiated plasma cells sometimes resemble the profile of an atypical pituitary adenoma, and immunohistochemical staining is required for definitive diagnosis of a plasmacytoma, ${ }^{3}$ as it happened in our case. Nearly half of the patients in their study initially presented with sellar plasmacytomas and ultimately had a subsequent diagnosis of multiple myeloma at full work-up or on follow-up. ${ }^{1}$ J. Lee et al., ${ }^{2}$ however, found only $37 \%$ of the patients diagnosed concurrently with myeloma on presentation of the parasellar plasmacytoma. Our case developed other symptoms that suggested the diagnosis of multiple myeloma just a few weeks after the procedure of partial resection of the sellar mass, even before the immune histopathological diagnosis.

\section{Conclusion}

Despite being rare, plasmacytoma should be considered as a possible diagnosis of sellar mass. It is found mainly in men, presenting with headache, diplopia, visual deficit, CN palsy (e.g., CN VI), imaging with cavernous sinus invasion and erosion of the parasellar bone. Increased awareness of this rare tumor and its clinical features can help clinicians to develop an appreciation for the importance of accurately diagnosing and effectively managing patients with sellar/parasellar plasmacytomas.

\section{Highlights}

- Sellar plasmacytoma should be considered as differential diagnosis of sellar masses.

- Sellar plasmacytoma is more common in elderly men.

- The most common symptoms are headache and diplopia, due to cranial neuropathies.

- Sellar plasmacytoma can present before diagnosis of multiple myeloma.

\section{Conflict of Interests}

The authors declare that there is no conflict of interests.

\section{References}

1 DiDomenico J, Ampie L, Choy W, et al. Sellar plasmacytomas masquerading as pituitary adenomas: A systematic review. J Clin Neurosci 2018;50:20-23. Doi: 10.1016/j.jocn.2018.01.022

2 Lee J, Kulubya E, Pressman BD, et al. Sellar and clival plasmacytomas: case series of 5 patients with systematic review of 65 published cases, Pituitary. https://doi.org/10.1007/s11102-0170799-5

3 Jin L, Gui S, Li C, et al. Differential Diagnosis and Treatment Modality of Parasellar Plasmacytoma: Clinical Series and Literature Review. World Neurosurg 2018. Doi: 10.1016/j.wneu.2018.10.183 